TEME, г. XLI, бр. 4, октобар - децембар 2017, стр. 1141-1144

Приказ дела

Примљено: 22. 4. 2017.

Одобрено за штампу: 15. 11. 2017.

\title{
ДА ЛИ ЈЕ ПРИМЕЊЕНО ПОЗОРИШТЕ КУЛТУРОЛОШКА ИЛИ ТЕАТРОЛОШКА ЧИЫЕНИЦА?*
}

\section{Милена Драгићевић Шешић}

Универзитет уметности, Факултет драмских уметности, Београд, Србија msesic@gmail.com

Књига Дарка Лукића ${ }^{1}$ Увод у примењено казалиште: Чије је казалиште? свакако је међу првим књигама у Хрватској, али и ширем региону, које нас уводе у свет примењеног позоришта на методолошки прецизан, а интелектуално изазован начин. Она указује на „невидљиве појаве”, позориште друкчијих, позоришне представе које настају на маргини, на друштвеној периферији - па чак и кад успеју да дођу до извођења у позоришним институцијама - и даље не остварују видљивост унутар етаблираног позоришног система које чува своју хегемонску позицијуㄹ.

О политичности позоришта (а реч политика треба овде схватити у најширем значењу те речи) на овом терену је први пут најбоље проговорила књига под називом Повијест политичког позоришта Зигфрида Мелхингера (Siegfried Melchinger), преведена и објављена у Загребу још 1989. године. Са

\footnotetext{
* Дарко Лукић, Увод у примијењено казалиште: Чије је казалиште?, Leykam Загреб, 2016.

${ }^{1}$ Дарко Лукић, редовни професор Академије драмских умјетности у Загребу, до сада је објавио бројне књиге у домену театрологије, од којих издвајамо: Драма ратне трауме (2009, Загреб: Меандармедиа), Казалиште у свом окружеюу, два тома (Загреб: Leykam International, 2010. и 2011. године), Увод у антропологију изведбе. Коме треба казалиште? (Загреб: Leykam International).

${ }^{2}$ Без обзира на то што Битеф полифонија већ годинама отвара свој простор овом типу позоришног рада, у критикама и написима о Битефу изостају критике ових позоришних дела, које у најбољем случају могу да очекују „информацију” - вест да су се уопште десила. Позоришни пројекти које су остварили значајни позоришни уметници - попут Радионище интегращије са слепим и слабовидим особама (Мики Манојловић) или представа остварених у психијатријским клиникама и центрима против сексуалног насиља (Зорица Јевремовић) - не добијају простор у позоришним дебатама, а да се не говори о представама које остварује Друштво за заштиту деце са Дауновим синдромом, или Друштва за заштиту аутистичне деце, без обзира на то што су први наступали пред препуном салом Југословенског драмског позоришта, а други у Позоришту на Теразијама.
} 
друге стране, поменута књига Дарка Лукића, објављења након 30 година, сигурно ће имати исти такав значај у овом тренутку јер овом питању приступа на радикално другачији, времену примерен начин - уводећи партиципативност и кокреацију као кључне методе овог приступа и начина рада.

Сви ови различити облици позоришног активизма о којима пише Дарко Лукић усмерени су, са једне стране, на конкретне циљне групе, а са друге, то су позоришта која утичу у ширем смислу на промену вредности, покрећу нове идеје у друштву, доприносе промени колективне свести о различитим питањима, како у својој заједници и најближем окружењу тако и у ширем социјалном контексту. Дарко Лукић нам својом анализом показује веома разноврсне позоришне праксе, које полазе од бројних тековина позоришне алтернативе чија су настојања да редефинише позоришну уметност и њене изведбе усмерене ка проналажењу њене праве формуле за 21. век. Кад кажемо проналажења праве формуле, мислимо управо на враћање различитих публика позоришту и позоришној уметности, остваривању позоришног чина и изван наменске театарске зграде, тј. ширењу доступности и позоришног стваралаштва и рецепције.

Дарко Лукић се у свом истраживању ослања на многобројне ауторе који разјашњавају са̂м појам и метод примењеног позоришта који је изведен из пракси шездесетих година, када се у оквиру различитих друштвених покрета, а посебно контракултуре, позориште укључује у борбу за корените друштвене промене и када је друштвени активизам у стопу пратила одговарајућа критичка мисао и уметничка експериментаторска пракса: позориште анимације и друштвене интервенције на пример, о којем сам детаљније писала у својој књизи Уметност и алтернатива (ФДУ и КЛИО, 2012).

У литератури Дарка Лукића подједнако се срећу и активистичка дела практичара Аугуста Боала (Augusto Boal), као и дела филозофа Алена Бадијуа (Alen Badiou), феминистички погледи Батлерове (Butler) и Сју-Елен Kejc (Sue-Ellen Case), као и допринос хрватских ауторки Надежде Чачиновић и Ладе Фелдман, најновији теоријски радови из домена културне политике Данијеле Клиш (Danielle Cliche) и Раџа Исара (Raj Isar), регионални доприноси теорији уметности (Бојана Цвејић, Сергеј Присташ) и практичном раду примењеног позоришта (Александра Јелић) - да се не набраја даље све то сведочи о мултиперспективистичком и интердисциплинарном приступу аутора. Цитирају се и изучавају часописи који су непознати позоришној јавности у региону (Applied Theatre Research, Independent Living Institute Newsletter, Disability Studies Quarterly итд.).

Оно што аутор врло добро примећује као проблемско место свих прича о позоришту, па и примењеном позоришту, јесте публика, тј. њено одсуство или невидљивост управо оних публика којима су позориште и драма најпотребнији: обесправљени појединци (на разне начине), маргинализовани и маргинализоване. То су публике којима позориште као елитна институција државе још од старе Грчке до данас никада нису била заправо доступна; сетимо се да управо у старој Грчкој у театрон нису могли да уђу жене, деца и робови иако су у трагедијама Есхила, Софокла и Еурипида управо они били главни протагонисти. Ни данас није другачије. Јавна позоришта, тежећи наводној уметничкој изврсности, заправо фактички запостављају највећи број грађана и грађанки, не узимајући у обзир по правилу нити једну социјалну групу којој је истински потребна помоћ у социјалној инте- 
грацији (поготово када је реч о лицима са инвалидитетом и другим најугроженијим категоријама друштва).

Тематски, књига покушава да ове парадоксе невидљивих и реалних публика расветли путем разних извора и стратегија академског истраживања, што није лак задатак. Лукић најрелевантније ауторе (попут Прендергаста (Prendergast), Сакстона (Saxton), Пренткија (Prentki) и других) из овог поља театрологије укључује кроз бројне цитате, изузетне библиографске референце, док врло вешто теоријска знања и практична искуства контекстуализује на примерима локалних пракси у Хрватској.

Лукић не занемарује ни историјски преглед рада и настанка саме форме/стратегије примењеног позоришта, у распону од позоришта корена, соиијалног позоришта, политичког Пискаторовог и Брехтовог револуционарног прегнућа из прошлог века, затим Боаловог Позоришта потлаченог, те радикалних политичких перформативних изведби из шездесетих, до позоришта у образовању и драме у образовању британских традиција 20. века. Дарко Лукић у својој студији историјско чуло обједињује са практичним и савременим контекстима „у потрази за почецима” оног што данас може да се подведе под легислативно позориште, тј. позориште за друштвене промене, тзв. примењено позориште у најужем смислу те речи.

Појам примењеног позоришта, у смислу методологије која је заснована на процесу, а не продукцији као таквој, затим колективном радионичком стварању самог текста и реперкусијама на са̂м почетак промене свести у публици/извођачу/ осетљивим групама - у Лукићевој студији добија свој пуни смисао, нарочито ако се узме у обзир које све сегменте друштвеног живота је аутор успео да покрије и синергички проанализира: правне документе, скенирање друштвено-политичке климе како у транзицији тако и у неолиберализму, друштвени активизам у оквирима често херметичног трећег сектора, те у оквиру институција културе и институцијама система, јавност и не-подршка, правна регулатива vs. покрети алтернатива, сукоб на левици и десници, студије случаја итд.

Јасно је да Увод у примењено казалиште: Чије је казалиште? већ у самом наслову позива на даља истраживања, али исто тако позива и садашње практичаре, којих, као што и сам аутор наводи, има мало (а и они су често, премда добронамерни, недовољно едуковани, па самим тим и мање видљиви и са често упитним резултатима) да своја знања и промишљања о свом раду на друштвеној инклузији преиспитају са различитих становишта, да уђу бар у дијалог једни са другима. Са друге стране, аутор са правом много више критички приступа институцијама које без довољно обазривости и ентузијазма приступају сегменту инклузије у оквиру сопствених дневних пракси (као испуњавању културно-политичких налога), пре свега у домену осмишљавања стратегија и програма за лица са инвалидитетом: од приступних рампи до релеватнтних тема, те и самих техничких услова за специфична извођења. Оно што је очигледно јесте одсуство посвећености и сензибилитета радника у култури за елементарне потребе ових популација, као и изостанак непрестаног рада на унапређењу услова бар за неопходна „прилагођавања” при извођењима, што би омогућило доступност и маргинализованој публици.

Сама студија Увод у примењено казалиште: Чије је казалиште? академски је активизам по себи, али онај који проговара (и преговара) са самим 


\section{4}

проблемима друштвеног хуманизма у временима опште флуидности идентитета, идеја и идеологија, политика (уметничких и културних), укључујући и оне свима заједничке - прекаритет, експлоатација и глобална економска и духовна оскудица. Оно где успева за сада инклузивно уметничко стваралаштво, као што и са̂м аутор признаје, јесу земље развијених демократија, што наравно не оправдава земље у транзицији да се на ову тему више не упуте, едукују и делају у оквиру својих локалних заједница; било самоорганизовано или пак интерсекторски повезано.

Укратко, ова књига је изузетно потребна јавности у целом региону, како академској тако и професионалној. Она представља оригинално научно дело, релевантно, методолошки студиозно изведено, прегледно, дајући могућност различитих читања и служећи као инспирација како у домену независног театра тако још и више као подстицај институционалном театру да промисли о својим могућностима инклузивног деловања. Она ће без сумње имати своју читалачку публику без обзира на то да ли су у питању уметници-професионалци, активисти или једноставно радознала публика, али и стручњаци из различитих домена социјалног рада који желе да буду упознати и уведени у оне форме позоришног деловања које доприносе друштвеној промени, развоју јавних политика и пракси. Укратко, то је веома корисна и важна књига за широки круг професионалаца, али и за културну јавност, те посебно за јавне и културне политике, јер указује на значај позоришта у реализацији изузетно важних друштвених промена, остваривању права на културу и доступности културе, као основних задатака демократске културне политике. 